\title{
Remarks on the Crustacea of the Pacific Coast, with de- scriptions of some New Species.
}

\author{
BY W, N. LOCKINGTON.
}

Notwithstanding the small number of sheltered bays and coves to be found along the shores of the Pacific Ocean, south of Vancouver's Island, the Crustace appear to be tolerably abundant, since the total number of species of the two highest orders, (the stalk-eyed and sessile-eyed) known or described up to this date, is about two hundred and twenty, and there is every reason to believe that a more searching investigation would at least double that number.

Neither Dana nor Stimpson did much work at the Crustacea south of San Francisco, and the species lately described by Smith are almost entirely from Panama. Between Panama and San Francisco lies a vast extent of coast, extending through nearly twenty-nine degrees of latitude, and embracing a region greatly diversified in climate and productions, so that although many San Franciscan species extend southward a considerable distance, and many Panama species may range along Central America, it is but reasonable to suppose that many undescribed forms have their limits between those extremes.

The reasonableness of this expectation will be rendered the more apparent by a glance at a map showing the ocean temperature. That portion of the ocean bathing the shores of California at San Francisco, belongs to the subtemperate oceanic zone included between the isothermal lines of $500^{\circ}$ Faht. and $56 \circ$ lowest cold, but the heat of the ocean increases rapidly as we travel southward, so that the coast from Monterey to San Diego, and for some distance south of the latter place, lies between the isothermal line of $56^{\circ}$ extreme cold and that of $62 \circ$. The greater part of Lower California, with the Gulf, is included within the line of $62 \circ$ extreme cold and that of $688^{\circ}$, and may be called warm temperate. From Cape St. Lucas to about the latitude of Acapulco is the sub-torrid zone, the isothermal line of $74 \circ$ degrees lowest cold bounding it toward the south, and forming the northern limit of the torrid oceanic zone which extends to, or near to, Guayaquil, in the State of Ecuador.

Since Panama is situated close to the oceanic heat equator, it will be seen that in the 290 of latitude between San Francisco and that place there is a variation of about $30 \circ$ in the lowest temperature of the ocean, a difference which must and does imply a corresponding variation in the animal life inhabiting the ocean.

It was, therefore, with great pleasure that I received, since our last meeting, a small but choice collection of Crustacea, collected at Monterey and San Diego, by Mr. Henry Hemphill, and my pleasure was still greater when I found, upon comparison with the specimens already in our museum, and with the writings of Stimpson and S. I. Smith, that this donation enriched us with at least 20 species new to science.

Up to this present time no species of Crustacea from Panama, and only one or two from the coast intervening between that point and San Diego, 
have reached this Academy, and the amount of zoölogical riches yet remaining to be harvested in this quarter, may be guessed at from the fact that these twenty species were collected incidentally, as it were, the Crustacea not being the chosen field of the collector.

It is with some diffidence that I refer some of these species to their genera, simply because we have not in our collection specimens of many well known genera, nor have we in our defective library any figures or description of the already known species included in them.

To make clear to others the difficulty under which I and any other person who attempts to do a little original work in connection with this institution, are compelled to labor, I have but to state that two of the species described in this paper belong to a group of crabs, the macropodidae (distivguished by the great length and thinness of their legs), no species of which has before been known on this coast, but of which the typical forms are described and figured in such standard works as those of Milne Edwards, and Bell's British Stalk-eyed Crustacea, neither of which works are to be found in our library.

I have, therefore, in determining the genera, been compelled to be guided alone by the generic descriptions given by Dana in his Crustacea of U. S. Exploring Expedition, the only comprehensive work accessible to me, and that is lent to the Academy.

Before proceeding to the technical description of the new species, I wish to draw the attention of all members of the Academy at all interested in zoölogy, to a few peculiarities in our list of native Crustacea as it stands at present.

Two species of Macropodidae, as I have just said, are all that are yet known. The crabs of this tribe are sluggish in their habits and are usually found among sea weed, sponges and zoöphytes, at depths below those left bare at the lowest low tide, and are thus only obtained by dredging, unless cast ashore in some storm along with the sea weed among which they live. It is, therefore, almost a certainty that a properly organized search would disclose several other species, even in this immediate neighborhood.

Of the Xanthidae, a sub-family near the true cancer, not a single species has been described by Stimpson or Dana, and it is singular that among the newly found San Diego species this tribe predominates.

Only two species of the swimming crabs (Portunidae), have yet been found in California, one of these (Lupa bellicosa), has been described by Stimpson, and the other is new.

The parasitic Crustacea of various orders bave not yet been collected with any thoroughness, but I may here mention that several, (so far as I am aware) undescribed forms have recently been added to our collection, and that I hope, during the course of this year, to be able to prepare another paper upon them and upon other undescribed species not included in the present paper.

Neither the Entomostraca, which include the Cyclops, Cypris, Daphnis, and many other tribes, nor the Barnacles or Cirripedia of this coast have yet been studied, and I trust that this short enumeration of a few of the things that want doing may stir up some of our members to do them.

The collection of Crustacea in this museum now includes about 320 species, almest all from this coast or from the islands of the Pacific. Scarcely any 
European or Atlantic coast species, and none from South America, Australia or Africa, have yet reached us.

I have purposely made my technical descriptions short, giving only those salient characteristics which distinguish the species, but it is my hope to supplement these descriptions by a series of photographs of the new forms-a hope warranted by the present financially satisfactory state of this institution.

\section{Inachus tuberculatus.}

Rostrum, short, entire; pre-orbital spine marked only by the angle of the orbit; post-orbital spine slightly longer than the eyes; medial region of carapace with several small tubercles; posterior, with a large central tubercle surrounded by a ring of smaller tubercles; postero-lateral regions, with several small tubercles; all the regions prominent and separated by well marked depressions; three last joints of first pair of feet with scattered tubercles, manus stout; second pair of legs $2 \frac{1}{2}$ times the length of the post-rostral part of the carapace; sternum and abdomen with scattered tubercles.

Dimensions of two specimens:

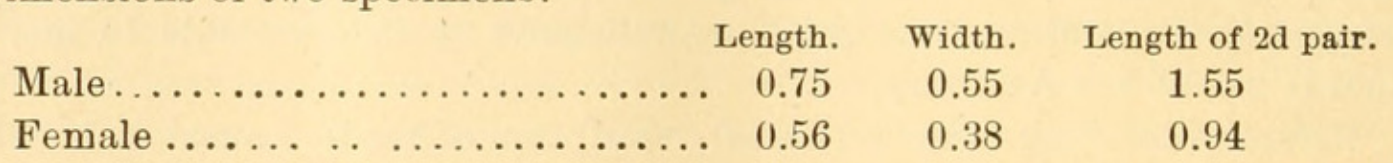

Dredged in eight fathoms, upon a rocky bottom covered with weeds, at the mouth of San Diego Bay, by Henry Hemphill. This, and the following species, are the first examples of the macropodidae found on the California coast.

\section{Microrhynchus Hemphillii.}

Rostrum, short, entire; form of carapace, long and narrow triangular; post-orbital spine, small; antero-lateral margin marked by a line of hairs; 1st pair of legs short, the meros extending to the line of the eyes; $2 d$ pair, more than three times the length of the post-rostral part of carapace; $3 \mathrm{~d}, 4 \mathrm{th}$, and 5th pairs diminishing in length, the last a little less than twice the length of post-rostral part of carapace. A few scattered hairs on the two last joints of the four hinder pairs of legs, especially on the fourth joint.

A single male specimen of this species was dredged, in seven fathoms of water, in the Bay of San Diego. Length, 0.75 ; width, 0.33 ; length of $2 \mathrm{~d}$ pair of legs almost two inches.

\section{Pisoides? tumidus.}

Rostrum, bifid, moderately long; no pre-orbital spine; post-orbital spine small; first joint of external antennae very wide, prolonged into a point externally. 1st and $2 d$ pair of legs about equal in length; hand of first pair, stoutish; fingers gaping when closed, the ends toothed and fitting neatly together; a large tubercle on movable finger in the centre of the gaping part. Carapace, with the regions tumid and spineless, smooth and rounded behind. A single specimen, male, was found between tides, near San Diego. The whole of the carapace and feet are covered with a short pubescence, becoming 
longer upon the margins of the limbs and forming a lamellate protuberance over the rostrum. Length, 0.65 ; width, 0.45 ; length of $2 \mathrm{~d}$ pair of feet, 0.80 .

\section{Lambrus frons-acutis.}

Carapace, transverse, somewhat pentagonal, each antero-lateral border having a rounded angle in the centre of its length; and the postero-lateral border forming an almost straight line with the posterior border. Rostrum, pointed, prominent, elevated, continuous with the elevated gastric region. A prominence at the cardiac region. Branchial regions prominent, each capped with a line of tubercles extending outward to the angle between antero and postero-lateral borders. Antero-lateral border finely toothed and terminating behind in an acute point. The portions of the carapace between the prominences are much depressed and perfectly smooth. Arm, carpus and hand of the first pair of legs, trigonal in section, each angle set with a continuous row of small tubercles. Dactylos turned inwards almost perpendicularly to the hand, very small. A single dried specimen brought from Santa Catalina. Length, 0.50 ; breadth, 0.70 ; breadth across arms when bent, 1.33 inch.

\section{Xantho spini-tuberculatus.}

Front four-lobed, areolets of anterior and antero-lateral portions of carapace prominent; six teeth on antero-lateral margin, including that of posterior angle of orbit; chelipeds covered with smooth shining tubercles on the upper portions, those of the hand arranged in seven longitudinal series; fourth and fifth joints of the four hinder pairs of limbs beset with spines on their superior portions.

Specimens from Santa Rosa, presented and collected by W. G. W. Harford. Specimens from Monterey, presented and collected by J. G. Cooper.

Specimens from San Diego, presented and collected by Henry Hemphill.

Length of carapace of male, 0.44 width, 0.63

$$
\text { " " } \quad 0.57
$$

\section{Xanthodes latimanus.}

Front sinuate, the inner angle of the orbit raised into a point; carapax but slightly transverse; teeth N. T. S., prominent and pointed, D and E almost obsolete. Areolation of medial and antero-lateral regions distinct, the former having the parts $2 \mathrm{M}$, and $3 \mathrm{M}$ entirely outlined. Hands, sub-equal, the right somewhat the larger; movable fingers very long, and curved abruptly downward; margin of manus continuous with the broad base of the fixed finger so as to form a sinuous sloping line; hinder feet compressed. This species may be readily identified by the delicate marbling of the carapace and chelipeds, and the downward bend of the movable fingers. Abdomen of male, five jointed.

A single male specimen from San Diego. Length, 0.73; breadth, 0.88 .

\section{Xanthodes Hemphillii.}

Front almost entire, slightly waved and somewhat produced; carapace, transverse, medial region prominently outlined; 1st antero-lateral tooth (D), 
almost obsolete; 2d, (E), long and low; 3d, (N), 4th, (T) and 5th, (S), pyramidal and pointed; cardiac region faintly outlined. 1st pair of feet, subequal, smooth; hands without crests or tubercles; fingers, black. The movable finger of the right hand with a large tubercle at base; $3 \mathrm{~d}, 4$ th and 5 th joints of four posterior pairs of feet compressed, fingers villous.

A single male specimen found at Monterey. Length, 0.82; width, 1.10.

\section{Xanthodes leucomanus.}

This species appears to be very nearly allied to $X$. Hemphillii, having the front antero-lateral teeth, and areolation of that species. If there is any value in the subdivision Xanthodes, both should be included in it, as both have the first antennal joint connected with the front by a process. The principal difference between the two forms, size excepted, will be found in the network of raised lines upon the upper portions of the hand and carpus of the chelipeds in the present form; and the almost entire absence of the tomentosity upon the four hinder pair, which characterizes $X$. Hemphillii. The dactyli of the chelipeds are of a shining, leucous tint when recent. Several specimens, from Santa Rosa Island (W. G. W. Harford); Monterey (J. G. Cooper); and San Diego (Mr. Henry Hemphill). The carapax of the largest specimen measures half an inch in width, and 0.34 in length.

\section{Xanthodes? novem-dentatus.}

Front rather narrow, prominent in centre, and produced forwards; teeth of antero-lateral margin, nine in number; carapace transverse; cbelipeds long, the right considerably the larger; manus long and rather narrow, with a slight double crest on the superior margin; corpus with several blunt spines; posterior feet somewhat compressed, with a few scattered hairs on the margins.

A single male specimen, from San Diego. Total length, 0.94; breadth, 1.25.

\section{Acanthus. Nov. gen.}

This genus is proposed for the reception of a singular species found at San Diego by Mr. Henry Hemphill. Its characters are: front, two-lobed, with a deep central emargination; antero-lateral margin, front, and whole circumference of orbit surrounded by long spines; carapax, narrow; antero-lateral and postero-lateral margins about equal in length; body, thick; abdomen of male, seven jointed. This genus appears to be near Pilumnus, but I can detect no trace of a praelabial ridge.

\section{Acanthus spino-hirsutus.}

Besides the generic characters given above, this species may be distinguished by ten spines upon the front, pointing straight forward; a group of four on each side the central emargination, and a single spine close to the outer antenna, the second joint of which reaches nearly to its extremity; six or seven spines on lower margin of orbit, and four larger spines on antero-lateral margin of carapax, besides those on upper margin of orbit. Front portion of carapace and upper parts of all the feet thickly covered with 
long stiff hairs, mixed, on the chelipeds only, with spines similar to those of the front of carapace. The whole upper surface of the carapax, the meros of the fifth pair of feet, and the posterior portion of the sternum are covered with a short and thick pubescence. Right hand considerably the larger; fingers of both hands with several large, blunt teeth or tubercles on their inner margin. The spines upon the hands change gradually to tubercles as they approach the fingers.

Length, one inch; breadth of carapace, 1.12.

\section{Eucrate? Califormensis.}

Surface of carapace smooth, very slightly granulate close to margins; anterolateral margin three-toothed; carapace level transversely, but considerably curved longitudinally; abdomen of male five-jointed; right hand considerably larger than the left; hand broad and thin; laminate on superior margin; carpus with a spine on the interior distal margin; four hinder pairs of legs rounded, tarsi pointed.

The aspect of this species is exactly that of Stimpson's Speocarcınus Carolinensis, as figured in Notes on North American Crustacea, No. 1, but the abdomen is different.

Width, 1.06 inch; length, 0.82 inch.

The only specimen (dried) is from San Diego.

\section{Pseudosquilla marmorata.}

Carapace much narrowed in front, as in Squilla, but the body stiff and without carinæ upon the thoracic or abdominal segments, except upon the two last. Penultimate segment with two central spines flanked on each side by two lateral ones; a central carina, and five lateral ones on each side of the apical segment of abdomen. The central carina terminates in a spine, flanked just beneath by the two movable spines, counting from which, on each side are, 1st, a small blunt spine; $2 \mathrm{~d}$, a small acute spine; $3 \mathrm{~d}$, a large acute spine; 4 th, a very small acute one; and 5th, a bluntish spine formed by the union of the two outermost carinæ of the last abdominal segment; the penult joint of the caudal appendages armed with nine spines, the last as long as the last joint of those appendages; first joint of caudal appendages prolonged backwards into a spine almost as long as the remaining two joints, and armed on its inner edge with two strong spines; antennary plate produced into an acicular spine, movable finger with two spines only on its interior edge; three movable spines at proximal end of manus.

The whole of the upper surface of this rare and beautiful crustacean is marbled, in its dry state, with yellowish brown spots on a dark brown ground, while the tips of the caudal appendages are a vivid red.

Length, from tip of rostrum to tip of movable spines, 3.80 inches; of carapace only, $0.82 \mathrm{inch}$; width of abdomen, 0.63 inch.

This single speeimen in this collection was found at low tide, on sandy mud flats at San Diego.

This and Squilla De-saussurei, Stimpson, are, so far as I am aware, the only Stomapoda yet discovered on the shores of California.

Proc. Cal. Acad. Sci., Vol. VII.-3. 


\section{Crangon nigromaculata.}

Carapace with a single spine on the gastric region near the rostrum, and a larger spine on each hepatic region. Suborbital and antennal spines present. Inner antennæ about equal in length to movable scale of outer antennæ, and the base of outer antennæ about half as long as its movable scale; Dactylos of first pair of feet tranererse, short; an oval black spot on each side of the abdomen just anterior to the caudal processes.

Three specimens from San Diego, dredged in six fathoms of water.

Total length of largest specimen from tip of antennal scale to tip of tail, $2 \frac{1}{2}$ inches; of body from tip of rostrum, 2.06 inches.

This species can readily be distinguished from all others by the black spot upon each side of the tail; it appears to be nearly"allied to $C$. nigricauda.Stimpson.

\section{Crangon Alaskensis.}

Rostrum very short and pointed; spines of carapace, as in nigromaculata: inner antennæ scarcely as long as movable scale of outer antennæ; movable finger of first pair of legs rather long, oblique; hands, carapace, and abdomen in preserved specimens (alcoholic), clothed with minute black spots.

This species may be distinguished from $C$. nigricauda, which it much resembles, by the greater obliquity of the palm of the hand, the different coloration, and the smaller size.

Length of body, 1.45 inches.

Several specimens from Mutiny Bay, Alaska, preșented by the U. S. Coast Survey.

\section{Alpheus bellimanus.}

At the time of the publication of Stimpson's Crustacea and Echinodermata of the Pacific Shores, no species of Alphous had been detected in California, but recently two species have been collected by Mr. Henry Hemphill, of San Diego. The present species may be easily recognized by the beautiful coloring of its hands, which, in a dried specimen, are orange, with various spots and workings of black and white.

Movable finger of larger hand small, depressed, and closing in a plane oblique to that of the manus, which is furnished with a spine on its outer edge, and a second beneath, has a toothed margin opposed to that of the dactylos, and presents two longitudinal grooves on its under surface, the anterior groove terminating in a transverse depression; in the smaller hand the dactylos is laminate and in the same plane with the hand, which has an exterior spine like that of larger hand, and another on its inferior surface. The fixed finger of the larger hand is longitudinal, and has an almost straight edge; the annulations of the carpus of second pair are only four in number; there is no tooth on the lower apex of the third joint of the third and fourth pairs of legs.

Two specimens from San Diego, found among kelp.

Length of larger specimen, from joint of rostrum to end of abdomen, 1.20 inches; length of larger hand, half an inch, of smaller, 0.38.

The carapace presents traces of a similar coloration to that of the hands. 
Alpheus equidactylus.

A single dried specimen, broken, from Monterey, is all that we possess of this very distinct species. The larger hand has a transverse sulcus immediately posterior to the finger, and the movable and fixed fingers are of equal length and extended in the same place with the hand. The rostrum is narrow and sharp.

Length, 0.75 inch. The fingers of the chelae shut close together when the hand is closed.

\section{Betceus longidactylus.}

Form much more compressed than in alpheus bellimanus; hands similar in form; long and compressed; the fixed finger half the length of the hand, the movable one more than half that length; the fingers when closed gape widely; both are pointed at the end, and the points cross each other like the mandibles of a Loxia. At the origin of the movable finger are several teeth, opposed to two large ones upon the hand itself, which also bears a large tooth in the centre of the length of the fixed finger.

Color of carapace of dried specimen, green, with nuances of russet and olive. The fingers of the larger hand are light red, the tips green.

Length of carapace, $1.12 \mathrm{inch}$; of larger hand, 0.56 inch; of smaller, $0.36 \mathrm{in}$.

A single specimen from Sản Diego, on a sandy mud flat, between tides.

\section{Hippolyte? Hemphillii.}

I give this provisional name to a single specimen (dried), brought from San Diego by Henry Hemphill. Several of the feet are wanting, and the specimen is distorted so as to render a detailed description impossible. The rostrum is short and has four teeth, besides the long terminal tooth. The limbs are handed transversely with alternate dark and light tints.

Length, 1 inch.

\section{Hippolyte lineata.}

Rostrum less than half the length of the carapace, armed with seven teeth on the upper side (including the terminal one), and three on the lower; the two hinder teeth only are on the carapace, and are longer, but not highes thar the others; outer maxillipeds reaching to the tip of the movable scale of outer antennæ; hands of first pair small and slender. The most noticeable characteristic of this species is the presence of eight longitudinal lines of a tint lighter than the ground color of the body. Upon the carapace these eight lines become broken up, and mingled with other markings, producing a pattern resembling that of watered silk. Two dried specimens from San Diego, collected between tides, and one larger one, in alcohol, presented by Henry Edwards.

Length of largest specimen, from tip of rostrum to end of abdomen, $2 \frac{1}{2}$ inches. 


\section{Idotoa rectilinea.}

Body, slender; not increasing in width backwards; all the segments of the thorax equal in width, and the abdomen rectilinear, nearly as wide as the thorax; first two segments of abdomen, distinct; total length of abdomen about equal to that of last three thoracic segments; posterior extremity obtusely pointed. Thoracic segments equal in length. Outer antennae, long; the peduncle equal in length to the three first segments of body; flagellum broken in both specimens. Color, various; one dried specimen almost entirely black, the other with a black line down centre of body, the rest of which is yellowish.

Length, 0.80 inch. "Width, 0.17 inch. San Diego.

\section{Serolis carinatus.}

Thorax and abdomen conspicuously keeled upon the centre of every segment; the first segment slightly waved on its posterior margin, the curve of the segments increasing rapidly, in such a manner that the last entirely encloses the free abdominal segments on their sides. Caudal segment rounded at the extremity, with two marginal teeth on each side, at a considerable distance from the extremity, the central carina running the entire length of the segment; last basal joint of inner antennæ longer than the flagellum; flagellum of outer antennæ much shorter than either of the two of the preceding basal joints, and last basal joint about equal in length to the penultimate. Eyes large, reniform, conspicuous. The texture of the upper surface of a dried specimen, under a two-thịds power, has a somewhat squamate appearance. Color, a grayish brown, diversified with dots and irregular markings of black; hands long and slender; dactylos equal in length to the manus.

Two specimens from San Diego. Length, 0.21 inches; width, 0.16 inches.

T. A. Blake read portions of a petition to Congress, from the Boston Society of Civil Engineers, relating to the adoption of the Metric system of weights and measures.

On motion, the Chair was requested to appoint a committee in regard to the memorial.

The Vice-President informed the Academy that Dr. Gerhard Rohlfs had kindly consented to lecture before the Academy upon his travels in Africa during the years 1860 and 1867; the lecture to be delivered the Monday following this announcement.

On motion of Dr. Stout, Dr. Rohlfs was invited to become the guest of the Academy during his stay in San Francisco.

The judges of election reported having duly filed the certificate of election with the County Clerk. 


\section{$2 \mathrm{BHL}$ Biodiversity Heritage Library}

Lockington, W N. 1877. "Remarks on the Crustacea of the Pacific coast, with descriptions of some new species." Proceedings of the California Academy of Sciences 1876, 28-36. https://doi.org/10.5962/bhl.part.27534.

View This Item Online: https://www.biodiversitylibrary.org/item/22477

DOI: https://doi.org/10.5962/bhl.part.27534

Permalink: https://www.biodiversitylibrary.org/partpdf/27534

\section{Holding Institution}

MBLWHOI Library

\section{Sponsored by}

MBLWHOI Library

\section{Copyright \& Reuse}

Copyright Status: NOT_IN_COPYRIGHT

This document was created from content at the Biodiversity Heritage Library, the world's largest open access digital library for biodiversity literature and archives. Visit BHL at https://www.biodiversitylibrary.org. 